\title{
Los implantes MG-Osseous. Estudio multicéntrico retrospectivo
}

\author{
MG-Osseous implants. A multicentric retrospective study
}

Los autores reflejan en este trabajo su experiencia con la utilización de un sistema de implantes de diseño español y fabricación norteamericana: MG-Osseous. Se trata de un sistema de implantes de titanio de diseño roscado y superficie tratada RBM.

Durante la década de los ochenta, existía un número relativamente pequeño de sistemas de implantes dentales. Los implantes evolucionaron lentamente durante esa década, y todos los cambios de su diseño o superficie eran avalados por años de estudios experimentales y clínicos. ${ }^{1,2}$

En las décadas siguientes, el número de compañías que fabricaban implantes creció de forma explosiva, en relación al incremento de la demanda por parte de la población general de este "nuevo" tratamiento. La presión comercial y la competencia entre las distintas casas comerciales provocaron que, en muchas ocasiones se introdujeran en el mercado nuevos diseños y superficies, con poca o ninguna literatura científica que los avalase. ${ }^{3,4}$ Este fenómeno se ha acentuado en los últimos años. En el entorno actual altamente competitivo, cada casa comercial intenta introducir constantemente "novedades" que diferencien su producto de la competencia. Ya no suelen esperar años para realizar estudios de sus productos antes de su introducción en el mercado, y muchas veces son los propios clínicos los que tienen que "probar" esas novedades en los pacientes de sus consultas. Este escenario no es el más deseable, desde el punto de vista médico.

El tiempo de seguimiento implantológico en la mayoría de los estudios publicados se fue acortando desde los 5 y 10 años iniciales, ${ }^{5}$ a tan solo 12-18 meses. ${ }^{6,7}$ Los estrictos criterios de éxito aplicados inicialmente, ${ }^{8}$ se dejaron de utilizar en muchos estudios, siendo sustituidos por el menos exigente porcentaje de supervivencia de los implantes. Todo ello ha conducido a que los resultados publicados en los estudios sean cada vez mejores, y se aproximen cada vez más al límite "imposible" del $100 \%$ de éxito.9,10

Los tiempos de espera antes de cargar los implantes se han ido reduciendo progresivamente. De seis meses se ha pasado a tres meses, luego a semanas, días u horas. Por otra parte, los criterios de inclusión y exclusión también han cambiado, y muchas situaciones que eran consideradas contraindicaciones relativas para la colocación de implantes han dejado de serlo en la actualidad (pacientes diabéticos, fumadores, o con osteoporosis, son incluidos rutinariamente en muchos estudios actuales). Aunque estos hechos deberían haber conducido, "a priori", a un empobrecimiento de los resultados, finalmente no ha sido así, probablemente por el cambio de las antiguas superficies maquinadas lisas a las nuevas superficies irregulares tratadas, que permiten alcanzar mejores resultados. ${ }^{11,12}$
In this work the authors describe their experience with an implant system designed in Spain and made in North America: MG-Osseous. This is a titanium implant system with a self-tapping design and a surface that has been treated with RBM.

During the decade of the eighties there was a relatively small number of dental implant systems. Implants developed slowly during this decade, and all the changes in designs or surfaces were backed by years of experimental and clinical studies. 1,2

During the following decades, the number of companies making implants grew enormously in relation to the increase in demand from the general public for this "new" treatment. Commercial pressure and competition among the different companies led to new designs and surfaces being introduced into the market, on many occasions with little or no scientific literature to support them. ${ }^{3,4}$ This phenomenon has been+ accentuated in recent years. In today's highly competitive market, companies are constantly trying to introduce "new features" in order to differentiate their product from that of their competitors. No longer do they wait years while studies of their products are carried out before introducing them into the market. On many occasions it is the clinicians themselves that have to "try out" these new treatments on patients coming to their surgeries. From the medical point of view, this is not the best scenario.

The follow-up time in implantology in most of the studies published has become shorter and shorter, and it has gone from being initially 5 to 10 years, 5 to as little as 1218 months.6,7 The strict success criteria applied initially were no longer used in many studies, and they were substituted by a less demanding implant survival percentage. All this has led to published results being better every time, and they are fast approaching an "impossible" $100 \%$ success rate. 9,10

The waiting period for implant loading is being reduced progressively. This has gone from six to three months, then down to week, days and hours. On the other hand, inclusion and exclusion criteria have also changed, and many situations that were considered inadvisable with regard to implant placement have stopped being so at the present time (diabetic patients, smokers, those with osteoporosis are routinely included in most of the current studies). Although this should have led to the results being poorer "a priori", this has not been the case, probably as a result of changes in the 
También han caído muchos paradigmas iniciales de la osteointegración. Se ha ido pasando de protocolos de 2 fases quirúrgicas a protocolos de 1 sola fase, a la colocación inmediata de implantes postexodoncia, y a la rehabilitación inmediata en días u horas de la"estética" o de la "función" perdidas por el edentulismo. 13-17 En ocasiones, los protocolos quirúrgicos "tradicionales" han sido sustituidos por la colocación transmucosa de las fijaciones, ${ }^{18}$ guiadas o no por férulas diseñadas mediante software informático específico. ${ }^{19-21}$ Muchos clínicos exponen en cursos y conferencias, casos de pacientes a los que se les realizó simultáneamente exodoncias múltiples, legrado de lesiones infecciosas periapicales, colocación de implantes y prótesis inmediata, violando en mayor o menor medida los protocolos "tradicionales", que exigían esperar un tiempo prudencial entre cada una de las fases del tratamiento. ${ }^{22-24}$ En este contexto cambiante donde parece que "todo" vale, es muy importante no perder de vista la esencia que la implantología aportó en sus orígenes: estudios científicos que avalen o no las "aparentes" ventajas de los nuevos diseños y superficies de los implantes introducidos en el mercado por las casas comerciales.

El trabajo que tenemos el gusto de comentar es un estudio clínico multicéntrico, en el que participan profesionales de distintos puntos de nuestra geografía. El número de pacientes e implantes incluido en el estudio es alto: 247 pacientes y 1001 implantes. Todo ello aporta validez al estudio y hace previsible que se puedan reproducir estos resultados en otros estudios de similares características. En contraposición, el diseño del estudio es retrospectivo, por lo que probablemente, el índice de complicaciones registradas en el mismo ha sido inferior al que se habría obtenido en un diseño análogo, pero prospectivo.

En su estudio los autores refieren un porcentaje de supervivencia de los implantes del $97,8 \%$. Estos resultados son excelentes, y comparables con las mejores series publicadas sobre implantes de superficie tratada. La superficie Ti-Unite de Nobelbiocare está documentada con estudios prospectivos con un seguimiento de 1 a 2 años y una tasa de fracasos del $3 \% .{ }^{25}$ Las superficies SLA de Straumann cuenta con estudios prospectivos que documentan una alta eficacia clínica (99\% de éxito) y un seguimiento a 1-2 años. ${ }^{26} \mathrm{La}$ superficie Osseotite de $3 \mathrm{i}$ está avalada por estudios clínicos prospectivos con un porcentaje de éxito del $95-99 \%$ y seguimiento de hasta 5 años. ${ }^{27,} 28$ La superficie Tio-blast de Astra Tech cuenta con estudios que documentan buenos resultados con un seguimiento de más de 7 años. ${ }^{29}$

Para conseguir un porcentaje de supervivencia tan alto, los autores han aplicado una filosofía de tratamiento "tradicional" y prudente, incluyendo solo ocasionalmente en su serie, casos de implantes inmediatos postexodoncia $(2,89 \%)$, casos de carga inmediata $(2,19 \%)$ y de implantes transmucosos $(1,29 \%)$. Personalmente, es una filosofía que compartimos, intentando disminuir al máximo los fracasos en nuestros pacientes.

Los autores también han sido cuidadosos y prudentes en la selección de los pacientes incluidos en su estudio. El tipo de implante más frecuentemente usado en el trabajo ha sido el de diámetro estándar $(3,75 \mathrm{~mm})$ y longitudes largas $(13$ y $15 \mathrm{~mm})$. El porcentaje de injertos utilizados no ha sido alto $(88,43 \%$ de los implantes no han necesitado técnicas de regeneración ósea). Todo ello nos older, smooth machined surfaces to the new irregular, treated surfaces that allow better results to be achieved. ${ }^{11,12}$

Many of the initial paradigms regarding osseointegration have fallen by the way side. Single-phase protocols are replacing two-phase protocols. Now we find immediate placement of implants after extraction, and there is immediate rehabilitation in days or hours for those edentulous patients needing "aesthetic" or "functional" restorations.13-17 On occasions "traditional" surgical protocols have been substituted by transmucosal fixture placement guided or not by splints designed by specific computer software. ${ }^{19-21}$ Many clinicians report cases in courses and conferences of patients undergoing multiple simultaneous extractions, curettage of periapical infectious lesions, placement of implants and immediate prostheses, violating to a greater or lesser degree the "traditional" protocols that require waiting for a prudent space of time between each treatment phase. 22-24 In this constantly changing context where it would seem that "everything goes" it is very important not to lose sight of the original concept behind implantology: scientific studies that support or not the "apparent" advantages of the new implant designs and surfaces that are introduced into the market by companies.

The work we have the pleasure of discussing is a clinical study that is multicentric and professionals from different areas of the country participate in it. The number of patients and implants included in the study is high: 247 patients and 1001 implants. All this gives the study authenticity and it is foreseeable that these results will be reproduced in other similar studies with similar characteristics. By comparison, the design of the study is retrospective and probably the rate of complications has been lower than if it had been an analogous but prospective study.

In their study the authors report an implant survival percentage rate of $97.8 \%$. There results are excellent and comparable with the best series published on implants with treated surfaces. The Ti-Unite surface from Nobelbiocare has been documented in prospective studies with a 1-2 year followup and a failure rate of $3 \% .{ }^{25}$ The SLA surfaces from Straumann are backed by prospective studies that show high clinical efficiency (99\% success rate) and a follow-up of 1-2 years. ${ }^{26}$ The Osseotite surface from $3 \mathrm{i}$ is backed by prospective clinical studies with a success rate of 95-99\% and a follow-up up to 5 years. ${ }^{27,28}$ The Tio-blast surface from Astra Tech is backed by studies with good results and a follow-up of more than seven years. ${ }^{29}$

In order to achieve such a high survival rate, the authors have applied a philosophy of "traditional" prudent treatment, and they have included only occasionally in their series cases of implants placed immediately after extractions (2.89\%), cases of immediate loading (2.19\%) and transmucosal implants (1.29\%). This is a philosophy that we personally share in an attempt to reduce the failure rate in our patients to the maximum.

The authors have also been careful and prudent with regard to the selection of patients included in the study. The 
hace pensar que ha existido una juiciosa selección de los casos incluidos en la muestra, que probablemente haya contribuido al excelente porcentaje de osteointegración de las fijaciones expuesto por los autores en su trabajo.

Los resultados del estudio se refieren, como en la mayoría de los trabajos actuales, al porcentaje de supervivencia de los implantes (consideran como "fracaso" solo los implantes retirados por falta de estabilidad). Si se hubieran aplicado criterios de éxito más estrictos, como los descritos por Smith y Zarb, ${ }^{8}$ sería razonable haber encontrado un porcentaje de complicaciones mayor.

El periodo de estudio de los pacientes incluidos es relativamente corto. Aunque en el trabajo se hace referencia reiteradamente a un seguimiento de " 2 años", en el estudio se recoge que los implantes fueron colocados en los años 2004 y 2005, que la mayoría (68,24\%) se hicieron en dos fases quirúrgicas, y que el tiempo de espera para la segunda fase y comprobar la osteointegración de las fijaciones variaba entre 3 y 6 meses. Todo ello parece indicar que el tiempo de seguimiento de los más de mil implantes incluidos en el estudio, realmente ha variado desde pocos meses (para los últimos implantes colocados) hasta un máximo de 2 años (para los primeros implantes del estudio). Este tiempo de observación es excesivamente corto, dato que comparten muchos de los estudios actuales. Por regla general, se considera que las complicaciones registradas durante el primer año de carga de prótesis son de origen quirúrgico, mientras que las registradas posteriormente serían de origen protésico. Si el tiempo de seguimiento hubiese sido mayor, el índice de complicaciones presumiblemente habría crecido. ${ }^{30}$

En resumen, se trata de un estudio que resume la experiencia de un grupo de cirujanos españoles con un implante de diseño nacional. El porcentaje de supervivencia de los implantes conseguido es excelente, probablemente reflejo del adecuado diseño y fabricación del implante y de la gran experiencia clínica y quirúrgica de los autores.

Sería deseable, que todas las casas comerciales dispusiesen de estudios de similares características antes de la introducción de sus productos en el mercado. Y de forma ideal, de estudios multicéntricos prospectivos con un tiempo de seguimiento mayor (mínimo 5 años), 31,32 en el que, además del \% de supervivencia de los implantes, se analizasen otros criterios de éxito como el mantenimiento del hueso crestal, ${ }^{33}$ o el resultado estético de las restauraciones.

Jaime Baladrón Romero Médico especialista en Cirugía Oral y Maxilofacial. Práctica Privada (Oviedo, España).

Luis Manuel Junquera Gutiérrez Médico especialista en Cirugía Oral y Maxilofacial. Escuela de Estomatología. Hospital Central de Asturias (Oviedo, España) type of implant most commonly used in the study is the one with the standard diameter $(3.75 \mathrm{~mm})$ and longer lengths (13 and $15 \mathrm{~mm}$ ). The percentage of grafts used was not high (88.43\% of the implants did not need bone regeneration techniques). All this suggests that the cases included in the sample were selected wisely and that this probably contributed to the excellent rate of osseointegration of the fixtures reported by the authors in their work.

The results of the study refer, as in most of the current studies, to the percentage of implant survival (only the implants removed because of lack of stability are considered a "failure"). If stricter criteria had been applied, such as those described by Smith and Zarb, finding a higher complication rate would have been reasonable.

The study period of the patients included in the study is relatively short. Although the paper refers repeatedly to a follow-up of "two years" the study mentions that the implants were placed in 2004 and 2005, that most (68.24\%) were placed in two surgical phases, and that the waiting period for the second phase and for checking the osseointegration of the fixtures varied between three and six months. This would seem to indicate that the follow-up time of the more than one thousand implants included in the study, has in reality ranged from a few months (for the last implants placed) to a maximum of two years (for the first implants in the study). This observation period is extremely short, as is that of many of the current studies. As a general rule, the complications registered during the first year of prosthetic loading are considered to have a surgical origin, while those registered later are of a prosthetic origin. If the follow-up period had been longer, the rate of complications would presumably have increased. ${ }^{30}$

In short, this is a study that sums up the experience of a group of Spanish surgeons with an implant designed in Spain. The survival rate for the implants is excellent. This probably reflects the adequate design and manufacturing of the implant, and the extensive clinical and surgical experience of the authors.

It would be desirable for all companies to have studies of similar characteristics before the introduction of their products on the market. And ideally, multicentric prospective studies should have a longer follow-up time (a minimum of five years), 31,32 and that, in addition to survival as a percentage rate, other criteria for success be used such as crestal bone preservation ${ }^{33}$ or the aesthetic results of the restorations. 


\section{Bibliografía}

1. Breine U, Branemark PI. Reconstruction of alveolar jaw bone: An experimental and clinical study of inmediate and preformed autologous bone grafts in combination with osseointegrated implants. Scan J Plas Reconstr Surg 1980; 14:23-8.

2. Adell R, Eriksson B, Lekholm U, Branemark PI, Jemt T. Long-term followup study of osseointegrated implants in the treatment of totally edentulous jaws. Int J Oral Maxillofac Implants 1990;5:347-59.

3. Albrektsson T, Wennerberg A. The impact of oral implants - past and future, 1966-2042. J Can Dent Assoc 2005;71:327.

4. Albrektsson T, Wennerberg A. Oral implant surfaces: Part 2--review focusing on clinical knowledge of different surfaces. Int J Prosthodont 2004; 17:544-64.

5. Jemt T, Chai J, Harnett J, y cols. A 5-year prospective multicenter followup report on overdentures supported by osseointegrated implants. Int J Oral Maxillofac Implants 1996;11:291-8.

6. Nowzari H, Chee W, Yi K, Pak M, Chung WH, Rich S. Scalloped dental implants: a retrospective analysis of radiographic and clinical outcomes of 17 NobelPerfect implants in 6 patients. Clin Implant Dent Relat Res 2006;8:1-10.

7. Cardaropoli G, Lekholm U, Wennstrom JL. Tissue alterations at implantsupported single-tooth replacements: a 1-year prospective clinical study. Clin Oral Implants Res 2006;17:165-71.

8. Smith DE, Zarb GA. Criteria for success of osseointegrated endosseous implants. J Prosthet Dent 1989;62:567-72.

9. Drago C], Lazzara RJ. Immediate occlusal loading of Osseotite implants in mandibular edentulous patients: a prospective observational report with 18-month data. J Prosthodont 2006;15:187-94.

10. Drago CJ, O'Connor CG. A clinical report on the 18-month cumulative survival rates of implants and implant prostheses with an internal connection implant system. Compend Contin Educ Dent 2006;27:26671.

11. Wagenberg B, Froum SJ. A retrospective study of 1925 consecutively placed immediate implants from 1988 to 2004. Int J Oral MaxiIlofac Implants 2006;21:71-80.

12. Anitua EA. Enhancement of osseointegration by generating a dynamic implant surface. J Oral Implantol 2006;32:72-76.

13. Malchiodi L, Quaranta A, D'Addona A, Scarano A, Quaranta M. Jaw reconstruction with grafted autologous bone: early insertion of osseointegrated implants and early prosthetic loading. / Oral Maxillofac Surg 2006;64:1190-1198.

14. Palmer RM, Palmer PJ, Baker P. Immediate and early replacement implants and restorations. Dent Update 2006;33:262-4, 266-8.

15. Yoo RH, Chuang SK, Erakat MS, Weed M, Dodson TB. Changes in crestal bone levels for immediately loaded implants. Int J Oral Maxillofac Implants 2006;21:253-61.

16. Martínez-González JM, Barona-Dorado C, Cano-Sánchez J, Fernández-Caliz F,Sanchez-Turrion A. Evaluation of 80 implants subjected to immediate loading in edentulous mandibles after two years of followup. Med Oral Patol Oral Cir Bucal 2006;11:E165-70.
17. Attard NJ, Laporte A, Locker D, Zarb GA. A prospective study on immediate loading of implants with mandibular overdentures: patientmediated and economic outcomes. Int J Prosthodont 2006;19:6773.

18. Oh TJ, Shotwell JL, Billy EJ, Wang HL. Effect of flapless implant surgery on soft tissue profile: a randomized controlled clinical trial. J Periodontol 2006;77:87482.

19. Jabero M, Sarment DP. Advanced surgical guidance technology: a review. Implant Dent 2006;15:135-42.

20. Lal K, White GS, Morea DN, Wright RF. Use of stereolithographic templates for surgical and prosthodontic implant planning and placement. Part II. A clinical report. J Prosthodont 2006;15:117-22.

21. Chow J, Hui E, Lee PK, Li W. Zygomatic implants--protocol for immediate occlusal loading: a preliminary report. J Oral Maxillofac Surg 2006; 64:804-11.

22. Melo MD, Shafie $H$, Obeid G. Implant survival rates for oral and maxillofacial surgery residents: a retrospective clinical review with analysis of resident level of training on implant survival. J Oral Maxillofac Surg 2006;64:1185-9.

23. Evian $\mathrm{Cl}$, Al-Momani A, Rosenberg ES, Sanavi F. Therapeutic management for immediate implant placement in sites with periapical deficiencies where coronal bone is present: technique and case report. Int J Oral Maxillofac Implants 2006;21:476-80.

24. Lindeboom JA, Tjiook Y, Kroon FH. Immediate placement of implants in periapical infected sites: a prospective randomized study in 50 patients. Oral Surg Oral Med Oral Pathol Oral Radiol Endod 2006;101: 705-10.

25. Glauser R, Ruhstaller P, Windisch S, y cols. Immediate occlusal loading of Branemark System TiUnite implants placed predominantly in soft bone: 4-year results of a prospective clinical study. Clin Implant Dent Relat Res 2005;7(Suppl 1):S52-59.

26. Cochran DL, Buser D, ten Bruggenkate CM, Weingart D, Taylor TM, Bernard JP, Peters F, Simpson JP. The use of reduced healing times on ITI implants with a sandblasted and acid-etched (SLA) surface: early results from clinical trials on ITI SLA implants. Clin Oral Implants Res 2002;13:144-53.

27. Testori T, Del Fabbro M, Feldman S, et al. A multicenter prospective evaluation of 2-months loaded Osseotite implants placed in the posterior jaws: 3-year follow-up results. Clin Oral Implants Res 2002;13:15461.

28. Mayer TM, Hawley CE, Gunsolley JC, Feldman S. The single-tooth implant: a viable alternative for single-tooth replacement. J Periodontol 2002;73:687-93.

29. Rasmusson L, Roos J, Bystedt H. A 10-year follow-up study of titanium dioxide-blasted implants. Clin Implant Dent Relat Res 2005;7:36-42.

30. De Bruyn H, Collaert B, Linden U, Johansson C, Albrektsson T. Clinical outcome of Screw Vent implants. A 7-year prospective follow-up study. Clin Oral Implants Res 1999;10:139-48. 